\title{
Youtube Videos and Snowball Throwing Technique to Improve Students' Speaking Skill
}

\author{
Nabella Dwi Meilinda \\ Teacher of English at Global English Language Center, Palembang, South Sumatera, Indonesia \\ nabellameilinda@gmail.com
}

\begin{abstract}
Snowball throwing technique is an interesting strategy which enables students to think and to discuss an issue from different points of view by using the video. This study was done to reveal if (1) there was a significant difference in the eleventh graders' speaking skill between those who were given intervention by using youtube video with a snowball throwing technique and those who were not, and (2) there was significant difference among good, average, and poor speaking categories among the sample. The participants of this study consisted of 106 eleventh graders of SMA Muhammadiyah 6 Palembang. By means of purposive sampling, 40 students were involved where 20 students of XI. Class IPA 1 was in control group and other 20 students of XI IPA 2 was in experimental group. This study used a quasi-experimental design with non-equivalent pretest and posttest design. To collect the data, speaking test was administered twice as the pretest and posttest for both groups. The result revealed that there was a significant difference in speaking skill between students taught by using youtube video with snowball throwing technique and those who were not. Last, there was a significant difference among good, average, and poor speaking categories among the sample.
\end{abstract}

Keywords: snowball throwing technique, speaking skill, youtube videos media

\section{Manuscript submitted: August 20, 2018 \\ Manuscript revised: September 5, 2018 \\ Accepted for publication: October 19, 2018}

\section{Introduction}

Every group of people in the world has their own languages. Clark argues that language is fundamentally an instrument of communication (as cited in Riyani, 2016, p. 1). These languages are the instrument for communication between one group and another. However, this language is learnt by a higher number of people with every passing day because it has two important things in this globalization era: (1) a means to communicate; and (2) to create a greater opportunity for a job (Crystal, 2003). However, language is not only used as an instrument to communicate but also to convey ideas, thought, opinions, and feeling.

Language is needed for daily communication. Without language, effective communication cannot be achieved and misunderstanding will take place. One of the languages is English, and it is used by millions of people around the world. It means that English is a means of global communication for many activities. Marzulina (2010) argues that communication happens from both listener and speaker to create a stimulus and response. The language helps us to express feelings, talk, exchange views, and contact people wherever we live by using the technologies such 
as computers and smartphone. It means that we have to be able to communicate in English and know how to practice it by technology.

This fact leads Indonesian people to learn English, and even the government has put English as a compulsory subject included in the curriculum. English is one of the tested subjects from the six important subjects required in national examination at senior high school (the Ministry of Education and Culture, 2013). Fiktorius argues that English examination is to measure students' English competence nationally (as cited in Carolina, 2017, p. 46). Based on the result from the Ministry of Education and Culture, in national examination 2013/2014, only 52, 69\% of the students who can give the responses in complete sentence. Wilkins says that the errors in learning are significant. They are not, however, entirely caused by differences between the native language of the learner and the language he is learning (as cited in Arif, 2015, p. 26). It means that the students still have problem in learning process.

In order to reach the success of English teaching, four language skills consisting of listening, speaking, reading, and writing must be taught in integrated way. However, EFL learners' ability to speak is still problematic. Hetrakul explains that the problems of student are resulted from two causes. The first is environment (outside the class) which does not support the students. The second is lack of grammar (as cited in Novita, 2017, p. 11).

According to Ur (1996), causes of speaking difficulties are many, such as: 1. Inhibition: it is a state of being anxious of making mistakes, receiving criticism, or being shy. 2. Nothing to express: it is a state of having no willingness to speak up. 3. Lack of participation: it is a state where there is one student talking at a time due to big class and the tendency of some students to dominate, while others have little or even no participation. 4. Vernacular use: students whose mother tongue is the same are likely to use it as it is easier and they feel less expose when using it. It is supported by Asiha Bibi that the main problem in learning English, the students are lack of grammar in particular how to make a sentence, how to use conjunction and verb based on the tenses (as cited in Astrid, 2011, p. 176). In this situation, speaking skill is more complicated than those other language skills. Shumin (2002) argues speaking English is the hardest skill for students as mastering speaking skill is not arduous. Speaking requires vocabulary, grammar, and a lot of practice. In addition, he said that the hardest part of speaking skill is that it is always done through communication with at least one other participant and this is why many language learners got shocked and upset when they used their second or foreign language for the first time in real communication: they were not ready yet for impromptu communication and could not deal with its simultaneous demands. Therefore, one of the skills that should be mastered is speaking skill (as cited in Dwinta, 2017, p.127). English speaking ability is very important for people to interact anywhere and anytime. This adds the importance of the teaching of speaking skill in mastering English, not only as foreign language (EFL) but also as second Language (ESL).

Burns and Joyce explain that Speaking is an interactive action of creating meaning through the process of receiving, processing, and producing information (as cited in Abrar et al., 2018, p. 130). In line with that Brown (2004) defines speaking as a productive skill which is observable. In addition, Efrizal (2012) describes that speaking is one of the ways of communication where ideas and thought are conveyed in oral form. To help students able to communicate, the application of the English language in real communication is needed. To overcome problems faced by students, teacher should find technique. According to Djamarah, technique is the way for achieving the goals set (as cited in Silfia, 2016, p. 46).

Various kinds of technique which can enhance students' speaking skill can be used. One of the recommended strategies is the snowball throwing technique. Snowball throwing technique is one of the teaching techniques that is based on the material is given by the teacher and the application in class like a group discussion to study English. According to the Ministry of National Education (2001), "Snowball throwing technique is one teaching technique that effective and that is 
recommended by UNESCO for learning to know, learning to do, learning to live, and learning to be"(p.5)

Snowball throwing technique could be optimal if it is supported by appropriate media. Hence, I had chosen youtube video to support the strategy in teaching and learning process. Indonesian government launched the newest curriculum called the 2013 curriculum, the teachers are required to integrate ICT into the EFL teaching and learning process. Moreover, Noni believes that use of ICT was believed to improve the quality of education, even increasing the effectiveness of learning (as cited in Khodijah, Zaini, \& Rhayati, 2015, p.184).

The resource, YouTube.com, is an online video repository in which nearly any digital video file can be stored and exhibited free of charge. Started in February 2005, youtube hosts videos that are cumulatively currently viewed more than 2 billion times each day ("Timeline," 2011). Currently, youtube has become more popular, especially among adults. This website provides learners with authentic situations and with everyday clips that help them to get better understanding of their lessons. Apart from that, Berk (2009) suggests that the use of video embedded in multimedia presentations to improve learning in higher education classes and it also has a strong effect on the mind and senses. Additionally, Greenberg and Zanetis (2012) report that video technologies, such as youtube video, can enhance students' cognitive and academic performance. This website provides learners with authentic situations and with everyday clips that help them to get better understanding of their lessons. Thus, it is assumed that using youtube video with snowball throwing technique is effective to solve the problem rather than others strategies in teaching speaking to the eleventh graders of SMA Muhammadiyah 6 Palembang.

The research problems in this study are: (1) Is there any significant difference in speaking achievement between the eleventh grade students of SMA Muhammadiyah 6 Palembang who were taught by using youtubevideo with snowball throwing technique and who are not? (2) Is there any significant difference among good, average, and poor categories of the speaking achievement of the eleventh graders of SMA Muhammadiyah 6 Palembang?

\section{Review of literature}

\section{Concept of speaking}

According to Brown, speaking is an interactive action of meaning making by producing and receiving and processing information (as cited in Yonsisno, 2015, p.40). Speaking as one of the four language skills plays vital role in communication. Bryne states that oral communication (or speaking) is a two-way process between participants in communication and requires the productive skill of speaking and the receptive skill of comprehending (as cited in Yonsisno, 2014, p. 37). When people start to speak, it means they want to deliver or share their ideas with others.

Brown (2004) further says that there are five basic types of speaking. They are described as follows: 1) Imitative. This type of speaking performance is the ability to imitate a word or phrase or possibly a sentence. 2) Intensive. This second type of speaking frequently employed in assessment context is in the production of short stretches of oral language designed to demonstrate competence in a narrow band of grammatical, phrasal, lexical or phonological relationships. 3) Responsive. This type is an interactive process which requires comprehension but at the fairly low level of very brief conversations, basic greeting and little talk, basic request and comments and the like. The stimulus is usually a spoken prompt in order to preserve authenticity. 4) Interactive. Interaction can happen through two forms of transactional language to share particular information, or interpersonal exchanges, which have the purpose of maintaining social relationships. 5) Extensive. Extensive oral production tasks include speeches, oral presentations, and storytelling, during which the opportunity for oral interaction from listeners is either highly limited or ruled out altogether. 


\section{Teaching speaking}

According to Brown, teaching is the specific act of assisting someone to be able to do particular things, deliver instructions, guiding in learning things by providing knowledge with the purpose to know or understand (as cited in Zahara, 2017, p.67).

Darling-Hammond argue that in improving education, there are many aspects which have to be considered because all aspects are important in improving students learning (as cited in Ghazali, Rabi, Wahab, \& Rohaizad, 2017, p. 41). It includes assessment, well-prepared teachers, welldesigned and coherent curriculum and also a skilful instruction which is adapted to students' needs and personalized learning environments.

Teaching speaking is sometimes considered as a simple process of commercial language school around the world, which hires people with no training to teach conversation. Lauder argues that English is well-known as an important language for Indonesia because it is an international language used globally. In Indonesia, English language teaching has been growing fast (as cited in Saputra \& Marzulina, 2015, p.1). It is taught in schools, especially secondary shools. Although Nunan (2003) states that speaking is totally natural, speaking in a language other than our own is anything but simple. Therefore, learning can be defined as a product of continuous interaction between the development and the life experience. More complex, Hamalik goals that learning means a conscious effort from a teacher to teach the students (directing the interaction of the students with the other learning resources) in order to achieve the expected (as cited in Imtihana, Sukirman, Mardeli, \& Nurlela, 2015, p. 37).

Teaching speaking in Indonesia is not easy. Most of teachers are focusing more on the content rather than practice. This is quite worrying because practicing has a big impact to improve the education. In improving education, there are many aspects which have to be considered because all aspects are important in improving students learning. Darling and Hammond believe that it includes assesment, well-prepared teacher, well-designed and coherent curriculum and also a skillful instruction which is adapted to students' needs and personalized learning environments (as cited in Ghazali, Rabi, Wahad, \& Rohaizad, 2017, p. 41).

Meanwhile, Aleksandrzak argues that the teacher should make the students fun in learning process (as cited in Herlina \& Holandyah, 2017, p. 108). If the students are not fun and interested in the lesson, the teacher will be very difficult to make the students understand the lesson. The teachers must create an interesting atmosphere in teaching learning process because the student's ability of learning English depends on their previous experience. Cowley explains that teaching style your personality, they way you look, the way you speak, the way you use movement and space, the levels of control you use in fact everything you do in give information the students (as cited in Saswandi, 2014, p. 39). It means that, teachers' teaching style is the teachers' personality about how the teachers transfer their information to the students and manage the situation in the class.

\section{The nature of the teaching of speaking skill}

Harmer (2001) explains that in teaching speaking, 6 principles are used which are as described here: 1) Help students overcome their initial reluctance to speak. Be encouraging; provide opportunity; start from something simple. 2) Ask students to talk about what they want to talk about. 3) Ask students to talk about what they are able to talk about. 4) Provide appropriate feedback. 5) Combine speaking with listening and reading. 6) Incorporate the teaching of speech acts in teaching speaking.

\section{The use of YouTube videos}

In relation to the use of technology, interactive multimedia is an example of technology which is widely used in the education real including in ELT. Lin and Chen argue that to cope with insufficient background knowledge of learning content, instructional strategies need to be merged 
into the learning material and one of the instructional strategies is by using multimedia (as cited in Pitaloka, 2014, p. 2). In this case, I used YouTube Videos as the multimedia to support the strategy. Smaldino, Russell, Heinich, and Molenda (2005) state that teachers can use YouTube videos to provide baseline knowledge for all students. The packaged media can serve as an alternative to teachers. 1) Cognitive skills. Students can observe dramatic recreations of historical events and actual recordings of more recent events. Color, sound and motion make personalities come to life. 2) Demonstrations. Videos are great for showing how things work. Demonstrations of motor skills can be more easily seen through media than in real life. If teachers are teaching a step by step process, teachers can show it in real time, speed up to give an overview or slow down to show specific details. 3) Virtual Field Trips. Videos can take students to places they might not be able to go otherwise. Teachers can take their students to the Amazon rain forest, the Jungles of New Guinea to observe the behavior of animals in the field. Teacher and students can go to those places and many others on videos. 4) Documentary. Videos are the primary medium for documenting actual events and bringing them into classroom. 5) Dramatization. Videos have the power to hold the students spellbound as a human drama unfolds before their eyes. 6) Discussion Basics. By viewing videos together, a diverse group of students can build a common base of experience as a catalyst for discussion.

\section{Types of videos}

Harmer (2001) states there are three basic types of videos which can readily be used in class. First, off-air programs. Programs recorded from a television channel should be engaging for students, and of a sensible length. Teachers have to consider their comprehensibility too. Apart from overall language level, some off-air videos are also extremely difficult for students to understand, especially where particularly marked accents are used or where there is a high preponderance of slang or regional vernacular. The programs and excerpts are ones which we can use for a range of activities including prediction, cross-cultural awareness, teaching language, or as spurs for the students' own activity. Teachers have to remember that all television programs have copyright restrictions which vary from country to country. It is important to know what the law is and realize that breaking it can have serious consequences.

Second, real-world videos. Teachers and students should not use separately published videotape material such as feature films, exercise manuals, wildlife documentaries or comedy provided that there are no copyright restrictions for doing this. Once again, teachers need to make their choice based on how engaging and comprehensible the extract is likely to be, and whether it has multi use potential. Teachers need to judge the length of the extract in the same way too. Third, language learning videos. It means videos to accompany course books. The advantage is that they have been designed with students at a particular level in mind. Those videos are likely to be comprehensible, designed to appeal to students' topic interests and multi use since they can not only be used for language study but also for a number of other activities as well.

\section{The concepts of snowball throwing technique}

Oxford claims that learning strategies make learning easier, faster, more fun, more independent, more effective, and more diverted to new situations. It is also supported by many studies that the use of language learning strategies may affect the ability of the students in foreign languages especially in English language skills (as cited in Marzulina, 2018, p. 64). So, one of the recommended strategies is snowball throwing technique.

Snowball throwing is one of teaching method that based on the material is given by the teacher and the application in class like a game to study English. Edmunds and Brown (2010,) said that snowball is recommended methods to improve interaction and one can set specific tasks for the other students in the group such as requiring them to ask questions, summarize key points, 
offer alternative views or comment on the content and quality of the presentation. Moreover, using a DVD clip or audio-recording is usually better to direct the students to look for and listen to specific features of the recordings. Farrel and Jacobs (2010) described that snowball throwing is a useful cooperative learning method because each member works alone first and then presents to the group, thus students are discouraged from either doing nothing or, the opposite, attempting to dominate the group. Sociologically, cooperative learning can foster self-awareness and altruism amongst learners and also enhance the importance of the individual in social life. The founder of cooperative learning is John Dewey in 1916 with his book "Democracy and Education". From the points above we can conclude that cooperative learning using the STT is a learning system that prioritizes the opportunities for the active participation of learners in learning especially for interactive dialogue. Because in the STT all the students get the opportunity to give and answer questions from other students in their group and they are required to participate actively in class. The technique facilitates the development of interactive dialogue between the student learners since one of the features of cooperative learning is group interaction. Furthermore, The STT is also able to increase the speaking ability of students because in these activities they will have different roles including having to speak. This means that they do not have to take the same responsibilities all the time since in this technique the students should formulate and answer questions properly and correctly.

\section{The advantages and disadvantages of snowball throwing technique}

Jaques and Salmon (2006) list the advantages of the STT as follows: 1) Good for encouraging the creation of well integrated ideas. 2) Allows students to think for themselves before discussing. 3) Generates full and lively participation in plenary discussion. From the explanation above, it is obvious that STT have many advantages such as; it can make the students used their ideas and creativity when answering the question without properly and correctly, so it can improve the students motivation in learning English, this technique facilitates the development of interactive dialogue between the students, and also it creates a lively classroom atmosphere because all the students must work in order to complete their tasks.

In contrast to the above advantages, the disadvantages of STT is it can break up cohesive feeling in some groups and takes time to unfold. Thus, in order to avoid these problems the teachers of English should be careful and aware of some potential problems before teaching in the classroom.

\section{Teaching procedures}

I adopted the teaching procedures from three stages of activities in teaching by using the snowball throwing technique proposed by Sanchez (2010) and modified the teaching procedures as needed for this present study. Thus, the procedures of teaching snowball throwing technique in both groups are listed: 1) Teacher prepares the material to be presented. 2) Each student finds a partner. 3) In each pair, students pose and answer a question or problem related to the topic they have studied. One person writes the question. The other person writes the answer on a separate sheet of paper. 4) The students ball up their papers. 5) The "question" students line up on one side of a line, rope, or ribbon. 6) The "answer" students line up on the other side. Both lines should be facing each other. 7) On the teacher's signal, the students throw their "snowballs" across the line. 8) At the teacher's stop signal, everyone picked up one snowball and tried to find the partner snowball. 9) In their new pairs, students read their question and answer, then use their resources (textbook, other print material available, posters, etc.) to verify the answer and to provide evidence (sources) that the answer is correct. If necessary, the students revise the answer. 10) Students can also use their work to create group or class resource books for that topic. 11) To facilitate learning 
by the students, the teacher helps them who have problems. To enrich the interaction among them, the teacher also pose some questions and asked for help to answer them from the students.

\section{Methods}

\section{Research design}

In this study, a quasi-experimental method, particularly pretest posttest control group design was employed to see the significant difference in speaking skill between the students who were given the treatment by implementing youtube videos with snowball throwing technique and those who were not to the eleventh graders of f SMA Muhammadiyah 6. Two groups were used in this study. The first group was experimental group and the second group was control group. The experimental and control groups were administered pretests and posttests but the treatment was only given to the experimental group.

\section{Population and sample}

Fraenkel and Wallen (2009) explain that population is bigger community of research interest to the researcher used to maka generalization of research results/findings. The population of this research, the eleventh grade students of SMA Muhammadiyah 6 Palembang in academic year of 2017/2018 were 106 students, comprising four classes; XI Ipa A, XI Ipa B, XI Ipa C, and XI Ips. Sample refers to groups of individuals from whom data are collected. McMillan and Schumacher (2010) state that in quantitative studies, the selection of the group of subjects or participants from the population is called sample. In deciding the sample of the study, I used purposive sampling method because I had an interview with one of the English teachers in SMA Muhammadiyah 6 Palembang. Then, the teacher recommended XI. IPA A and XI. IPA B class since they had the same characteristics and level of English. 40 students were taken from the population as the sample, 20 students as experimental group (XI IPA B) and 20 students as control group (XI IPA A).

\section{Data collection}

In this research, I used test. The kind of this test was a monologue test, based on the syllabus of 11th grade, they produce oral language by themselves. I used the pre-test and a post-test which were administrated before and after the treatment. The instrument which was used in both testswere the same instrument. Then, I considered the validity of the test prior to giving the test to the students. Brown (2004) defines validity as the degree to which the test actually measures what it is intended to measure. In this study, I applied content validity and construct validity to measure whether the instrument are valid or not. According to Hughes, content validity of an instrument is good if the content comprises materials representing the language skills, structures, etc. Furthermore, a test can be said to have construct validity when it measures what it is supposed to measure. (as cited in Putra \& Marzulina, 2018, p. 193). In this study, inter-rater reliability test were also used to find out the reliability of the result of students' speaking tests. It was checked by using raters' judgments on the language produced by students in terms of oral forms of English. After giving test, there were three raters involved in this study to give scores on students' speaking tests. To scores the speaking tests, the raters used Brown (2004) rubrics. The raters had selected based on three criteria: 1) they graduated from strata 2 of English study program; 2) they had minimum 3 years teaching experiences and 3) they had 550 for Toefl minimum scores.

\section{Data analysis}

Before the data were analyzed, frequency the data and descriptive statistics were counted to show distribution of the data. To interpret the students' individual score, the range of speaking 
ability used is as follows: excellent, good, average, poor, and very poor. In frequency of data, the students' scores, frequency, percentage were obtained from pretest and posttest scores in both experimental and control group. In descriptive statistics, number of sample, the score of minimal, maximal, mean, and standard deviation were also analyzed.

Furthermore, the data had to be checked for its normality and homogenity. For normality test, Kolmogorov Smirnov was used through SPSS program. For homogeneity test, Levene Statistics was also carried out. To analyze the data, I used t-test. It was run by SPSS version 22.0 software. There are two kinds of how to do t-test. In measuring a significant difference, students' posttest scores in experimental and control groups were analyzed through independent-sample t-test. The significant difference is indicated whenever p-output is less than 0.05. In measuring a significant difference among more than two variables, two-ways ANOVA was employed to analyze students' posttest scores in good, average, and poor categories in both groups. The significant difference was shown if the p-output (Sig. 2-tailed) does not exceeds 0.05 .

\section{Finding and Discussion}

\section{Distribution of students' speaking achievement in experimental and control groups}

First of all, the result of students' pretest scores in experimental group from 20 students showed that no students had speaking achievement in excellent and very poor categories, one student $(5 \%)$ was in good category, twelve students $(60 \%)$ were in fair category, and seven students $(35 \%)$ were in poor category. The result is presented in table 1 below:

Table 1. Distribution of data frequency on students' pre-test scores in experimental group

\begin{tabular}{cccc}
\hline $\mathbf{N}$ & Category & F & Percent \\
\hline \multirow{2}{*}{20} & Excellent & 0 & $0 \%$ \\
& Good & 1 & $5 \%$ \\
& Average & 12 & $60 \%$ \\
& Poor & 7 & $35 \%$ \\
& Very Poor & 0 & $0 \%$ \\
\hline & Total & $\mathbf{2 0}$ & $\mathbf{1 0 0 \%}$ \\
\hline
\end{tabular}

Meanwhile, the result in control group from 20 students revealed that no student belonged to excellent and very poor category of speaking achievement, two students $(10 \%)$ were in good category, fifteen students $(5 \%)$ belonged to fair category, three students $(15 \%)$ were categorized in poor category. The result of the pretest scores in control group can be seen in Table 2 below:

Table 2. Distribution of data frequency on students' pre-test scores control group

\begin{tabular}{lccc}
\hline $\mathbf{N}$ & Category & F & Percent \\
\hline $\mathbf{2 0}$ & Excellent & 0 & $0 \%$ \\
& Good & 2 & $10 \%$ \\
& Average & 15 & $75 \%$ \\
& Poor & 3 & $15 \%$ \\
& Very Poor & 0 & $0 \%$ \\
\hline & Total & $\mathbf{2 0}$ & $\mathbf{1 0 0 \%}$ \\
\hline
\end{tabular}

Secondly, the result analysis of students' posttest scores in experimental group from 20 students, it showed that there were seven students $(35 \%)$ in excellent category and twenty three students $(65 \%)$ in good category. It could be said that the students got better score after the treatment. The 
distribution of data frequency on the student's posttest scores in experimental group is described in Table 3 below:

Table 3. Distribution of data frequency on students' posttest scores in experimental group

\begin{tabular}{cccc}
\hline $\mathbf{N}$ & Category & $\mathbf{F}$ & Percentage \\
\hline \multirow{2}{*}{$\mathbf{2 0}$} & Excellent & 4 & $35 \%$ \\
& Good & 13 & $65 \%$ \\
& Average & 3 & $0 \%$ \\
& Poor & 0 & $0 \%$ \\
& Very Poor & 0 & $0 \%$ \\
\hline & Total & $\mathbf{2 0}$ & $\mathbf{1 0 0 \%}$ \\
\hline
\end{tabular}

Meanwhile, the posttest scores in control group showed that seven students $(35 \%)$ were categorized in good category, twenty students $(50 \%)$ were in fair category and three students $(15 \%)$ were in poor category. It meant that control group also got quite better score than before. This result is displayed in table 4 below:

Table 4. Distribution of data frequency on students' posttest scores in control group

\begin{tabular}{cccc}
\hline $\mathbf{N}$ & Category & F & Percentage \\
\hline \multirow{2}{*}{20} & Excellent & 0 & $0 \%$ \\
& Good & 4 & $35 \%$ \\
& Fair & 13 & $50 \%$ \\
& Poor & 3 & $15 \%$ \\
& Very Poor & 0 & $0 \%$ \\
\hline & Total & $\mathbf{2 0}$ & $\mathbf{1 0 0 \%}$
\end{tabular}

Thirdly, from descriptive statistics analysis, it was obtained that the maximum score of the pretest of the experimental group was 17, the minimum score was 7, the mean score was 11.95, and the score of the standard deviation was 2.946. Then, the maximum score of the pretest of the control group was 19 , the minimum score was 8 , the mean score was 13 , and the score of the standar deviation was 2.772. The result is presentend in Table 5 below.

Table 5. Descriptive statistics on students' pretest scores in control and experimental groups

\begin{tabular}{cccccc}
\hline Group & N & Min & Max & Mean & Std.Deviation \\
\hline Experimental & 20 & 7 & 17 & 11,95 & 2,946 \\
Control & 20 & 8 & 19 & 13 & 2,772 \\
\hline
\end{tabular}

Then, for posttest in the experimental group, the maximum score was 22 , the minimum score was 15 , the mean score was 18.15 , and the score of the standard deviation was 2.323 . Then, for posttest in controlgroup, the maximum score was 17 , the minimum score was 10 , the mean score was 13.35, and the score of the standar deviation was 2.109. The result is avaliable in Table 6 below. 
Table 6. Descriptive statistics on students' posttest scores in control and experimental groups

\begin{tabular}{cccccc}
\hline Group & N & Min & Max & Mean & Std.Deviation \\
\hline Experimental & 20 & 15 & 22 & 18,15 & 2,323 \\
Control & 20 & 10 & 17 & 13,35 & 2,109 \\
\hline
\end{tabular}

\section{The Results of Normality Test and Homogeneity Test}

A normality test was used to detemine whether sample data were distributednormally. For this reason, 1 Sample Kolmogorov-Smirnov in SPSS version 22.00 was used. The data are considered normal whenever it exceed 0.05 . The normality test result is presented in Table 7 below.

Table 7. Normality of the test of students' experimental and control group

\begin{tabular}{lcl}
\hline Groups & Scores & Sig. \\
\hline Control & Pretest & .200 \\
& Posttest & .151 \\
Experimental & Pretest & .200 \\
& Posttest & .120 \\
\hline
\end{tabular}

From the table above, the normality test results showed that the significance value in the control group was 0.200 for the pretest and 0.151 for the posttest. Then, the result of experimental group was 0.200 and 0.120 for the pretest and posttest. Thus, it can be concluded that the score distribution of both groups were normal. For knowing the homogeneity, Levene statistics was used all scores in experimental and control groups. The result of homogeneity test is displayed in Table 8 below.

Table 8. Homogeneity of test of students' pretest and posttest scores in experimental and control groups

\begin{tabular}{ccl}
\hline Group & Sig. & Category \\
\hline Pretest (Experimental-Control) & 0.454 & Homogenous \\
Posttest (Experimental-Control) & 0.338 & Homogenous \\
\hline
\end{tabular}

Based on the result, the significance level of students' pretest was 0.454 . Thus, it could be stated that the students' scores of pretest in experimental and control groups were homogenous since it was bigger than 0.05. Meanwhile, the significance level of students' posttest was 0.338. Thus, it could be said that the students' scoresof posttest in both groups were homogenous since it exceeded 0.05 .

\section{Significant difference of posttest scores in experimental and control groups}

Independent sample t-test was used to measure the significant difference on students' speaking skill by using snowball throwing technique and those who were taught by using teacher's method at SMA Muhammadiyah 6 Palembang. The result of independent sample t-test is displayed in Table 9 below. 
Table 9. Result of the analysis of independent sample t-test from students' posttest scores in control and experimental groups

\begin{tabular}{|c|c|c|c|c|c|c|}
\hline Group & Mean & $\mathrm{T}$ & Df & $\begin{array}{l}\text { Sig. (2 } \\
\text { tailed) }\end{array}$ & $\mathbf{H a}$ & Ho \\
\hline Control & 18,15 & & & & & \\
\hline Experimental & 13,35 & 6,841 & 38 & . 000 & Accepted & Rejected \\
\hline
\end{tabular}

Based on the table, it was found that the p-output was .000 and the t-value was $6.841 . \mathrm{It}$ showed that there was a significant difference on students' speaking skill by using snowball throwing technique because the p-output was less than $0.05(0.000<0.05)$ and the $t$-value was bigger than t-table $(6.841>$ df $38=2.429)$. Therefore, it indicates that the null hypothesis $(\mathrm{Ho})$ was rejected, and the alternative hypothesis $(\mathrm{Ha})$ was accepted. Moreover, it showed that $\mathrm{t}$ value was positive (6.841) meaning that mean score of student's posttest in experimental group was higher than in control group.

\section{Significant difference among good, average, and poor in control and experimental groups}

Two-way ANOVA was used to measure the significant difference on students' speaking skill taught by using youtube videos with snowball throwing technique and those who were not in (good, average, and poor) categories. The result of two-way ANOVA is avaliable in Table 10.

Table 10. The result of two-way anova from students' posttest scores in control and expermental groups in (good, average, and poor) categories

\begin{tabular}{cccccc}
\hline Source & $\begin{array}{c}\text { Type III } \\
\text { Sum of } \\
\text { Squares }\end{array}$ & Df & $\begin{array}{c}\text { Mean } \\
\text { Square }\end{array}$ & F & Sig. \\
\hline $\begin{array}{c}\text { Corrected } \\
\text { Model }\end{array}$ & $330.565^{\mathrm{a}}$ & 4 & 82.641 & 30.965 & .000 \\
Intercept & 4149.423 & 1 & 4149.423 & 1554.75 &. \\
Aspect & 90.027 & 2 & 45.014 & 16.866 & .000 \\
Group & 20.232 & 1 & 20.232 & 7.581 & .000 \\
Aspect $*$ & .668 & 1 & .668 & .250 & .009 \\
Group & 93.410 & 35 & 2.669 & & .620 \\
Error & 10315.000 & 40 & & & \\
Total & 423.975 & 39 & & & \\
\hline Corrected & & & \\
Total & & &
\end{tabular}

Based on analysis of two-way ANOVA from students' posttest scores in control group with 20 students and experimental group with 20 students in (good, average, and poor) categories. It could be seen that there were 20 students includes in good category, 17 students included in average category and 3 students included in poor category. The statistical analysis in measuring significant different more than two variable using two-way ANOVA found that the p-output was .620. From the p-output it can be stated that there is no different more than two variable of speaking category on students's speaking skill achievement taught using ST'T and conventional strategy because p-output was higher than 0,05. It means that there is no differences both categories good, average, and poor; snowball throwing technique and teacher's strategy can be applied in both of categories. 
From the finding above, I could conclude that there were some reasons why youtube videos with snowball throwing technique could improve the students' speaking achievements. First, it might be caused by some activities in teaching by using youtube videos with snowball throwing technique such as previewing, viewing, and post viewing activities which required the students to watch the videos by tapping their background knowledge, to respond to the videos or to practice some particular language point, and to stimulate their interest in the topic. In addition, after watching the videos, the students could discuss and share their ideas to one another in a group. This is also supported by Lialikhova's finding (2014) that proved the use of different pre-, whileand post-viewing activities can facilitate pupils' understanding of the video. The second reason why youtube videos with snowball throwing technique could improve students' speaking achievement was because the content of videos which exposed to real-life that can attract students' attention and make teaching and learning process more alive. This statement is strengthened by Flynn (1998) that video brings language in the context of life in realistic settings to the classroom. Hence, this strategy requires students to think and discuss the same topic in different point of view. Snowball throwing technique allowed the students to partcipate in brainstorming the idea and giving feedback each other confidently (Sanchez, 2010). Furthermore, by teaching snowball throwing technique, students felt enjoyable in speaking since the researcher paired up the students through. This statement is also strengthened by Amilia (2012) they could interact with their friends, such as asking and giving suggestion about their opinion each other.

The other reason why youtube videos could improve students' speaking achievement might be caused by its implementation. The students seemed excited and enthusiastic to watch the videos. They were also given the chance to analyses some events in the videos. It can also be implied that using videos could stimulate students to speak English, since they worked collaboratively in groups. Therefore, students could freely share their ideas each other.

The collaboration among students in one group could be a good way for those who were not confident to speak. In this case, the students were treated to use English to interact with others but they could ask some help and suggestions from others, including from I, whenever they found some problems in expressing something. Furthermore, in terms of speaking achievement, experimental group students made the highest improvement in vocabulary. It was because the students enriched their vocabulary during treatment by watching many kinds of YouTube videos. By doing so, they got new vocabulary as it was found in a study conducted by Ismaili (2013). However, there was one aspect, fluency, which showed the least significant improvement in experimental group. Probably, when I asked the students about the videos some of them were not ready to tell the event. They just focused on the fixed vocabulary which made them difficult to speak.

\section{Conclusions}

Several conclusions could be drawn based on the findings. Firstly, the snowball throwing technique was effective to enhance students' speaking ability of the eleventh graders of SMA Muhammadiyah 6 Palembang in academic year 2017/2018. It could be seen from the improvement they got after the intervention. The data showed that the snowball throwing technique had successfully encouraged students to have better speaking ability than those who were not taught by using this strategy.

To sum up the findings and interpretation above, following are several conclusions and suggestions to be considered. First, it could be concluded that snowball throwing technique significantly improved the students' speaking ability. It was found that the students in experimental group obtained higher score than those in control group after being taught by using snowball 
throwing technique. Moreover, In terms of aspects of speaking skills, there were also significant improvements in five aspects of speaking.

Second, there was significant difference in speaking ability between the students who were taught by using snowball throwing technique and those who were not. Hence, it could be concluded that the use of snowball throwing technique significantly improved the students' speakingskill.

\section{References}

Abrar,M., Mukminin, A., Habibi, A., Asyrafi, F., Makmur, M., \& Marzulina, L.(2018).If our English isn't a language, what is it? Indonesian EFL student teachers' challenges speaking English. The Qualitative Report, 23(1), 129-145.Retrievedfrom http:/ / nsuworks.nova.edu/tqr/vol23/iss1/9

Arif, N. (2015). Mother-tongue interference in the error of learners' grammar.IRJE: Jurnal Penelitian Universitas Jambi, 17(2), 26-30. Retrieved from https://onlinejournal.unja.ac.id/index.php/humaniora/article/view/2566

Astrid, A. (2011). Pembelajaran tata Bahasa Inggris secara komunikatif dengan penyajian induktif dan pengintegrasian keterampilan berbahasa: studi kasus di kelas Bahasa Inggris I di Iain Raden Fatah Palembang. Ta'dib: Jumal of Islamic Education, 16(2), 175-208. Retrieved fromhttp://jurnal.radenfatah.ac.id/index.php/tadib/issue/view/10

Berk, R. A. (2009). Multimedia teaching with video clips: Tv, movies, YouTube, and mtvU in the college classroom. International Journal of Technology in Teaching and Learning, 5(1), 1-21.

Brown, H. D. (2004). Language assessment: Principles and classroom practices. New York, NY: Longman.

Carolina, E. S. (2017). Are Islamic Boarding Schools Ready? The use of the computer-based test in the national exam policy for English subject. Ta'dib: Jurnal of Islamic Education, 22(2), 44-53. Retrieved fromjurnal.radenfatah.ac.id/index.php/tadib/article/view/1638.

Crystal, D. (2003). English as a global language (2nd ed.). Cambridge, CIE: Cambridge University Press.

Darusmin, D. K., Delfi, S., \& Masyhur. (2012). Using snowball throwing model to increase speaking ability of the second year students of SMP N 21 Pekanbaru. Faculty of Teacher's Training and Education, Riau University: Riau from bttp:/ / repository.unriac.id/ xmlui/ bitstream/ bandle/123456789/1318/JOURNAL\%20DENI\%20 KURNLANENGIH\%20DARUSMIN.pdf? sequence

Dwinta, D. A. (2017). Improving the eleventh grade students' speaking achievement through whole brain teaching method at Smk Farmasi Bina Medika Palembang. Edukasi: Jurnal Pendidikan Dan Pengajaran, 4(1), 125-136. Retrieved from jurnal.radenfatah.ac.id/index.php/edukasi/article/view/1521

Edmunds, S., \& Brown G. (2010). Effective small group learning. London, UK: AMEE Guide.

Education First, English Proficiency Index (2013). English proficiency index (3rd ed). Retrieved from http:// www.ef.com / efi

Efrizal, D. (2012). Improving students' speaking through communicative language teaching method at Mts Ja-alhaq, Sentot Ali Basa Islamic boarding school of Bengkulu, Indonesia. International Journal of Humanities and Social Science, 2(20), 127-134.

Farrel, T. S. C., Jacobs, G. M. (2010). Essential for successful English language teaching. New York, NY: MPG Book Group Ltd.

Fraenkel, J. R., Wallen, N. E., \& Hyun, H. H. (2012).How to evaluate research in education (8th ed.). New York, NY: McGraw-Hill.

Ghazali, N. H. C. M., Rabi, N. M., Wahab, N. A., \& Rohaizad, N. A. A. (2017). Development and validation of an inventory to evaluate teaching strategies for promoting higher-order thinking 
skills in the teaching of Islamic education. Ta'dib: Jurnal of Islamic Education, 22(1), 39-47. Retrieved from jurnal.radenfatah.ac.id/index.php/tadib/article/view/1217

Greenberg, A. D., \& Zanetis, J. (2012). The impact of broadcast and streaming video in education. Retrieved from http://www.cisco.com/web/strategy /docs/education/ cisco videowp.pdf

Herlina, \& Holandyah, M. (2015). Teaching speaking skill by using guided conversation technique through pair taping to the seventh grade students of SMP PTI Palembang. Edukasi: Jurnal Pendidikan dan Pengajaran, 2(2), 107-120. Retrieved fromjurnal.radenfatah.ac.id/index.php/edukasi/article/view/602

Harmer, J. (2001).The practice of English language teaching (3rd ed.). London: Pearson Education Limited.

Imtihana, A., Sukirman., Mardeli., \& Nurlela. (2015). The role of teaching Islamic religion at sekolah alam Indonesia Palembang. Ta'dib: Jurnal of Islamic Education, 20(1), 35-56. Retrieved from jurnal.radenfatah.ac.id/index.php/tadib/article/view/345

Jaques, D., Salmon, G. (2006). Learning in group: A bandbook for face-to-face and online environment (4th ed.). New York, NY: Taylor \& Francis Group.

Kementrian Pendidikan dan Kebudaayaan. (2013). Kerangka dasar dan struktur kurikulum 2013. Retrieved from http://sertifikasi.fkip.uns.ac.id/modul/1\%20 Materi $\% 20 K P P G \% 20 \& \% 20$ Kurikulum\%202013/STRUKTUR\%20DAN\%２0ISI $\% 20 K U R I K U L U M \% 202013 . p d f$

Khodijah, N., Zaini, H., \& Rhayati, E. (2015). The use of information and communication technology(by the lecturer of Islamic State University of Raden Fatah Palembang. Ta'dib: Jurnal of Islamic Education, 20(2), 183-200. Retrieved from jurnal.radenfatah.ac.id/index.php/tadib/article/view/328/pdf

Marzulina, L. (2010). Lecturer's roles and communicative functions in English education study program classroom of faculty of teacher training and education. Retrievedfromhttps:// scholar.google.com/scholar?cluster $=8120951589768271524 \&$ hl=en\&as_ $\mathrm{sdt}=2005 \&$ sciodt $=$

Marzulina, L. (2018). Learning strategy towards students' descriptive writing achievement taught by using pick-list -evaluate-active -supply-end strategy. Edukasi: Jurnal Pendidikan dan Pengajaran,3(1), 63-75. Retrieved from jurnal.radenfatah.ac.id/index.php/edukasi/article/view/2050

McMillan, J. H., \& Schumacher, S. (2010). Research in education: Evidence-based inquiry (7th ed). New York, NY: Pearson.

Ghazali, N. H. C., Rabi, N. M., Wahab, N. A., \& Rohaizad, N. A. (2017). Development and validation of an inventory to evaluate teaching strategies for promoting higher-order thinking skills in the teaching of Islamic education. Ta'dib: Jurnal of Islamic Education, 22(1), 58-68. Retrieved from jurnal.radenfatah.ac.id/index.php/tadib/article/view/1217

Novita, T. (2017). Students' English speaking skill and activation method: the case of one senior high school. Edukasi: Jurnal Pendidikan dan Pengajaran, 4(2), 10-17. Retrieved fromjurnal.radenfatah.ac.id/index.php/edukasi/article/view/1659

Pitaloka, N. L. (2014). Developing interactive multimedia with local-content-based narrative texts for grade eight. Lingua, Jurnal Bahasa dan Sastra, 15(1), 1-22. Retrieved from https://media.neliti.com/media/publications/219817-developing-interactive-multimediawith-l.pdf

Putra, H., \& Marzulina, L. (2016) Teaching reading comprehension by using content-based instruction (cbi) method to the second years learners at MTS al-furqon prabumulih. Edukasi: Jurnal Pendidikan dan Pengajaran, 2(2), 185-198. Retrieved from jurnal.radenfatah.ac.id/index.php/edukasi/article/view/608 
Riyani, R. (2016). Teaching narrative reading text by using $3 \mathrm{~h}$ (here, hidden, in my head) strategy to the tenth grade students of senior high school of Arinda Palembang. Edukasi: Jurnal Pendidikan dan Pengajaran, 3(1), 1-10. Retrieved from jurnal.radenfatah.ac.id/index.php/edukasi/article/view/619

Saputra, H., \& Marzulina, L. (2015).Teaching writing by using process genre approach to the eighth grade students of Smp Negeri 22 Palembang. Edukasi: Jurnal Pendidikan dan Pengajaran, 2(1), 1 12. Retrieved from jurnal.radenfatah.ac.id/index.php/edukasi/article/view/592

Saswandi, T. (2014).Teaching style and students' interest in learning English. IRJE: Jurnal Penelitian Universitas Jambi, 17(1), 33-39.Retrieved from https://media.neliti.com/media/publications/43487-EN-teaching-style-and-studentsinterest-in-learning-english.pdf

Silfia, E. (2016). Improving students' reading comprehension by using true-false sort at grade x apk of SMK N 2 Kerinci. IRJE: Jurnal Penelitian Universitas Jambi, 18(2), 41-48. Retrieved from https://online-journal.unja.ac.id/index.php/humaniora/article/view/3335/0

Sanches, P. (2010). Interactive classroom strategies Estuctures for success. New York, NY: Nicolas Sanchez.

Smaldino, S. E., Russell, J. D., Heinich, R., \& Molenda, M. (2005). Instructional technology and media for learning (8th ed.). Upper Saddle River, NJ: Pearson Education, Inc.

Timeline. (2011). YouTube.com. Retrieved from http://www.youtube.Com/t/ press timeline.

Ur, P. (1996). A course in language teaching from practice and theory. Cambridge,UK:University Press.

Yonsisno. (2014). Improving students' speaking skill by using role play technique at grade XI Ipa 1 of SMAN 2 Kota Sungai Penuh. IRJE: Jumal Penelitian Universitas Jambi, 16(2), 37-40. Retrieved from https://online-journal.unja.ac.id/index.php/humaniora/article/view/2034

Yonsisno. (2015). The effect of using debate technique toward students' speaking skill at the eleventh grade students of Sma Negeri 2 Kota Sungai Penuh. Jurnal Penelitian Universitas Jambi, 17(1), 40-44. Retrieved from https://onlinejournal.unja.ac.id/index.php/humaniora/article/view/2432

Zahara, I. (2017). The effectiveness of using guided discovery in teaching reading comprehension. Edukasi: Jumal Pendidikan dan Pengajaran, 4(2), 66-73. Retrieved from jurnal.radenfatah.ac.id/index.php/edukasi/article/.../pdf_1/ 